\title{
NILAI BUDAYA PINTU GEBANG CANDI KEDATON MUARA JAMBI
}

\author{
Oleh: Yola Katerina* \\ *Mahasiswa Program Studi Pendidikan Sejarah FKIP Universitas PGRI Palembang
}

\begin{abstract}
ABSTRAK
Candi Kedaton Muara Jambi yang kaya akan peninggalannya memiliki nilai sejarah yang tinggi makna nilai budaya pada tata letak pintu gerbang candinya. Permasalahan dalam penelitian ini adalah nilai budaya apakah yang terdapat pada pintu gerbang candi Kedaton Muara Jambi?. Tujuan dari penelitian ini yaitu: untuk mengetahui nilai budaya pintu gerbang pada candi Kedaton Muara Jambi. Metode yang digunakan dalam penelitian ini adalah deskriptif kualitatif Teknik pengumpulan data yaitu: dokumentasi, observasi, wawancara. Teknik analisis yaitu analisis interaktif, dengan beberapa komponennya antara lain pengumpulan data, reduksi data, display data verifikasi dan penarikan kesimpulan. Hasil penelitian nilai budaya pintu gerbang candi Kedaton Muara Jambi merupakan nilai budaya peninggalan agama Budha dari kerajaan Mataram Kuno, Sriwijaya, dan Malayu pada abad ke 9-12 Masehi dapat dilihat dari bentuk bangunan atau arsitektur.
\end{abstract}

Kata Kunci: Nilai Budaya Pintu Gerbang, Candi Kedaton

\section{A. PENDAHULUAN}

Indonesia terdiri dari sejumlah pulau besar dan kecil yang tersebar di sekitar garis khatulistiwa, menempati posisi geografis $95-1410$ BT dan 60 - 110 LS. Diapit oleh dua Samudera yaitu Samudera Pasifik dan Samudera Hindia. Serta diapit oleh dua Benua yaitu Benua Australia dan Asia. Menjadikan Indonesia sangat strategis letaknya. Letak posisi strategis demikian itu secara kalimatologis menimbulkan berlakunya suatu sistem angin tetap yang bertiup dari benua Australia ke Asia dan dari benua Asia ke Australia yang secara siklus bergantian tiap tahun karena letaknya di garis khatulistiwa. Indonesia berada di bawah pengaruh iklim tropis (Riandini, 2009:2-3).

Sumatera merupakan salah satu pulau dari enam buah pulau terbesar di dunia dengan luas daratnya sekitar 474.000 kilometer persegi (termasuk kepulauan di sebelah Barat dan Timur Sumatera). Merupakan pulau besar di bagian Barat Nusantara yang di bagi miring oleh khatulistiwa. Keadaan ini disebabkan karena pulau ini membentang dari barat laut ke tenggara yang dibagi dua bagian yang nyaris sama. Ujung barat laut di wilayah Daerah Istimewa Aceh (sekarang bernama Nangroe Aceh-Darussalam) terletak pada

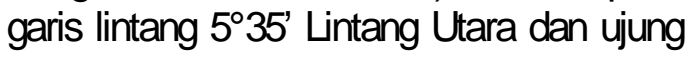
tenggara di wilayah Provinsi Lampung terletak pada garis lintang $5^{\circ} 56^{\prime}$ Lintang Selatan (Utomo, 2012:3).

$\mathrm{Di}$ daerah wilayah Sumatera tersebarlah wilayah kekuasaan Sriwijaya terutama di wilayah daerah Jambi, ini dibuktikan dengan adanya situs Muara Jambi sesudah terjadinya perubahan dinasti San-Fo-Tsi dari wangsa Syailendra ke wangsa Melayu, ibu kota San-Fo-Tsi yaitu Swarnabhumi telah berubah menjadi Chu chiang atau pelabuhan lama yang disebut Po-Lin-Fong. semenjak keruntuhan dinasti Syailendra Palembang tidak lagi berkedudukan sebagai ibukota (Ismail, 2003:151).

Sejarah merupakan suatu proses perjuangan manusia dalam mencapai tentang segala aktifitas yang di susun secara ilmiah dengan memperhatikan urutan waktu, di beri tafsiran atau analisa kritis, sehingga mudah dimengerti dan dipahami. 
Sejarah dapat memberikan gambaran dan tindakan maupun perbuatan manusia dengan segala perubahannya (Darini, 2016:7).

Muara Jambi merupakan sejarah peninggalan klasik pada masa kerajaan Sriwijaya dan Melayu Kuno yang dipergunakan dalam masa yang cukup panjang sejak awal 7 hingga $15 \mathrm{M}$, ini dibuktikan dari kutipan sumber sejarah kekaisaran Cina dan Kerajaan Majapahit yang berpusat di wilayah Jawa Timur. Pada tahun $671 \mathrm{M}$, komplek situs percandian Muara Jambi pernah dikunjungi pendeta Itsing, yang pernah singgah di Shi-li-fo-she (Sriwijaya) dan Mo-lo-yue untuk mendalami bahasa sansekerta selama beberapa bulan untuk berangkat ke Nalanda-India (Mundardjito, 2009:1). Kompleks percandian ini terletak di Kecamatan Muara Sebo, Kabupaten Muara Jambi, Indonesia tepatnya di tepi sungai Batang Hari, sekitar 26 kilometer arah timur Kota Jambi di pinggir sungai Batanghari (Ismail, 2003:153).

Candi Kedaton merupakan Candi terbesar di antara candi-candi yang lain di Kompleks Percandian Muara Jambi. Candi ini baru mulai ditampakkan pada tahun 1979. Letaknya sekitar 900 meter sebelah tenggara Candi Koto Mahligai, atau sekitar 1.580 meter di sebelah barat Candi Gedong II. Sungai Jambi yang merupakan pecahan dari Sungai Amburan Jalo berada 60 meter di Selatan, sedangkan 70 meter sebelah utara candi mengalir Parit Buluh yang juga berhubungan dengan Sungai Jambi. Candi Kedaton memiliki luas 45.000 meter persegi, atau sekitar 4,6 hektar,dengan pagar keliling yang membatasinya berukuran $215 \times 250$ meter (Purwanti, 2013:18).

\section{B. METODE PENELITIAN}

Metode penelitian deskriptif kualitatif, yang menggunakan cara mengumpulkan sumber-sumber secara sistematis dan menggunakan sumber data secara mendalam. Penelitian deskriptif kualitatif diuraikan dengan kata-kata menurut responden, apa adanya sesuai dengan pertanyaan penelitiannya, kemudian dianalisis dengan kata-kata apa yang melatar belakangi responden berperilaku (berpikir, berperasaan, dan bertindak) seperti itu tidak seperti lainnya, direduksi, ditriangulasi, disimpulkan (diberi makna oleh peneliti), dan diverifikasi (dikonsultasikan kembali kepada responden dan teman sejawat. Minimal ada tiga hal yang digambarkan dalam penelitian kualitatif, yaitu karakteristik pelaku, kegiatan, atau kejadian-kejadian yang terjadi selama penelitian, dan keadaan lingkungan atau karakteristik tempat penelitian berlangsung (Usman, 2014:130).

\section{HASIL DAN PEMBAHASAN Hasil Penelitian}

\section{Letak Candi Kedaton Muara Jambi}

Candi Kedaton terletak sekitar 1500 meter menuju arah Barat cari Candi Gedong 2, di sepanjang perjalanan menuju Candi Kedaton kita dapat melihat pada sisi kiri dan kanan jalan sebagian besar sudah di bangun warga sebagai tempat perkebunan yang di manfaatkan warga sebagai tempat bercocok tanam seperti, terong, timun, cabai, ranggam, pohon kopi, durian, duku, dan perkebunan karet. Untuk mencapai lokasi situs Muara Jambi ketempat Candi Kedaton terdapat 2 akses jalan yang digunakan, kendaraan roda dua (sepeda dan motor) maupun roda empat (mobil) yang jaraknya tidak jauh dari pusat kota Jambi, akses jalan yang di tempuh kurang lebih sekitar 5 menit dari jalan raya. Jika memalui jalan kaki melewati jembatan dan sungai Sebo, di tempuh jarah sekitar 30 Menit dari Kompleks percandian Muara Jambi melalui akses Sepeda atau motor yang melewati candi Gedong Dua dengan melalui jalan setapak yang menghubungkan Desa Muara Jambi dan Sengeti. karna ada dua akses jalan yang biasa dilakukan untuk sampai di Candi Kedaton. Waktu penelitian dilaksanakan selama 2 hari untuk mencoba 
menyelusuri jalan, dari tanggal 17 Maret 2017 sampai 18 Maret 2017 (Catatan Observasi lapangan No.1 dan No.2).

Wilayah Candi Kedaton dibatasi tembok pagar keliling yang berukuran $200 \mathrm{x}$ 230 membujur arah Utara Selatan. Tembok Candi Kedaton ini memiliki ketebalan dinding sekitar 1 meter, dan tinggi dinding pagar 232 Meter. Jarak dinding kekanal Timur sekitar 9 Meter. (Catatan Observasi Lapangan No.1).

Candi Kedaton baru mulai ditampakkan pada tahun 1979. Letaknya sekitar 900 meter sebelah barat candi Gedong II. Candi Kedaton merupakan Candi terbesar diantara candi-candi yang lain di Kompleks Percandian Muara Jambi. Candi ini baru mulai ditampakkan pada tahun 1979. Letaknya sekitar 900 meter sebelah tenggara Candi Koto Mahligai, atau sekitar 1.580 meter. Sungai Jambi yang merupakan pecahan dari Sungai Amburan Jalo berada 60 meter di Selatan, sedangkan 70 meter sebelah utara candi mengalir Parit Buluh yang juga berhubungan dengan Sungai Jambi (Purwanti, 2013:18-19). Lingkungan sekitar candi ini masih sangat alami, karna itu perlu penataan situs. Selain itu kegiatan penelitian dan pelestarian secara intensif, sebelum situs ini dikembangkan dan dimanfaatkan. karna itu pengamanan di daerah ini perlu diberi prioritas tinggi (Mundardjito, 2009:26).

Pada dasarnya Candi merupakan istilah yang digunakan untuk menyebut semua bangunan peninggalan di Indonesia yang dipengaruhi oleh arsitektur HinduBuddha. Istilah Candi dikaitkan dengan Candika yaiu salah satu nama Dewi Durga atau dewi kematian, sehingga Candi sering dikaitkan dengan kematian, makam atau sebagai tempat untuk memuliakan raja yang telah meninggal. Terkait dengan fungsinya sebagai pemakaman, sebenarnya yang tersimpan hanyalah pripih, yaitu sebagai wadah yang berisi antara lain zat-zat ragawi dari si mati seperti potongan rambut, kuku dan lain-lain. Pengertian candi sebagai tempat pemakaman hanya berlaku bagi penganut agama Hindu. Dalam agama Buddha, candi merupakan peribadatan atau tempat pemujaan (Darini, 2016:58).

Bentuk candi-candi di Indonesia adalah punden berundak, dimana punden berundak sendiri merupakan unsur asli Indonesia.

Berdasarkan bagian-bagiannya, bangunan candi terdiri atas tiga bagian penting, antara lain, kaki, tubuh, dan atap.

a) Kaki candi merupakan bagian bawah candi. Bagian ini melambangkan dunia bawah atau bhurloka. Pada konsep Buddha disebut kamadhatu. Yaitu menggambarkan dunia hewan, alam makhluk halus seperti iblis, raksasa dan asura, serta tempat manusia biasa yang masih terikat nafsu rendah. Bentuknya berupa bujur sangkar yang dilengkapi dengan jenjang pada salah satu sisinya. Bagian dasar candi ini sekaligus membentuk denahnya, dapat berbentuk persegi empat atau bujur sangkar. Tangga masuk candi terletak pada bagian ini, pada candi kecil tangga masuk hanya terdapat pada bagian depan, pada candi besar tangga masuk terdapat di empat penjuru mata angin. Biasanya pada kiri-kanan tangga masuk dihiasi ukiran makara. Pada dinding kaki candi biasanya dihiasi relief flora dan fauna berupa sulur-sulur tumbuhan, atau pada candi tertentu dihiasi figur penjaga seperti dwarapala. Pada bagian tengah alas candi, tepat di bawah ruang utama biasanya terdapat sumur yang didasarnya terdapat pripih (peti batu). Sumur ini biasanya diisi sisa hewan kurban yang dikremasi, lalu diatasnya diletakkan pripih. Di dalam pripih ini biasanya terdapat abu jenazah raja serta relik benda-benda suci seperti lembaran emas bertuliskan mantra, kepingan uang kuno, permata, kaca, 
potongan emas, lembaran perak, dan cangkang kerang.

b) Tubuh candi adalah bagian tengah candi yang berbentuk kubus yang dianggap sebagai dunia antara atau bhuwarloka. Pada konsep Buddha disebut rupadhatu. Yaitu menggambarkan dunia tempat manusia suci yang berupaya mencapai pencerahan dan kesempurnaan batiniah. Pada bagian depan terdapat gawang pintu menuju ruangan dalam candi. Gawang pintu candi ini biasanya dihiasi ukiran kepala kala tepat di atas-tengah pintu dan diapit pola makara di kiri dan kanan pintu. Tubuh candi terdiri dari garbagriha, yaitu sebuah bilik (kamar) yang ditengahnya berisi arca utama, misalnya arca dewa-dewi, bodhisatwa, atau Buddha yang dipuja di candi itu. Di bagian luar dinding di ketiga penjuru lainnya biasanya diberi relung-relung yang berukir relief atau diisi arca. Pada candi besar, relung keliling ini diperluas menjadi ruangan tersendiri selain ruangan utama di tengah. Terdapat jalan selasar keliling untuk menghubungkan ruang-ruang ini sekaligus untuk melakukan ritual yang disebut pradakshina. Pada lorong keliling ini dipasangi pagar langkan, dan pada galeri dinding tubuh candi maupun dinding pagar langkan biasanya dihiasi relief, baik yang bersifat naratif (berkisah) atau pun dekoratif (hiasan).

Atap candi adalah bagian atas candi yang menjadi simbol dunia atas atau swarloka. Pada konsep Buddha disebut arupadhatu. Yaitu menggambarkan ranah surgawi tempat para dewa dan jiwa yang telah mencapai kesempurnaan bersemayam. Pada umumnya, atap candi terdiri dari tiga tingkatan yang semakin atas semakin kecil ukurannya. Sedangkan atap langgam terdiri atas banyak tingkatan yang membentuk kurva limas yang menimbulkan efek ilusi perspektif yang mengesankan bangunan terlihat lebih tinggi. Pada puncak atap dimahkotai stupa, ratna, wajra, atau lingga semu. Pada candi-candi langgam, kemuncak atau mastakanya berbentuk kubus atau silinder dagoba. Pada bagian sudut dan tengah atap biasanya dihiasi ornamen antefiks, yaitu ornamen dengan tiga bagian runcing penghias sudut. Kebanyakan dinding bagian atap dibiarkan polos, akan tetapi pada candi-candi besar, atap candi ada yang dihiasi berbagai ukiran, seperti relung berisi kepala dewa-dewa, relief dewa atau bodhisatwa, pola hias berbentuk permata atau kala, atau sulursulur untaian roncean bunga.

Konsep dasar rancangan candi klasik Indonesia adalah keinginan menciptakan tiruan gunung pada pusat alam semesta, tempat roh para dewa dapat dibujuk untuk menjelma menjadi patung atau lingga yang ditempatkan dalam ruangan yang menyerupai gua. Arsitektur Indonesia Klasik paling awal terdiri atas tempat suci Hindu, dibangun di gunung api di Jawa Tenah. Secara raga dan perlambang, bangunan ini bersandar pada kepercayaan bahwa gunung merupakan tempat kekuatan adikodrati. Setelah "elit" yang berkuasa mulai membangun dengan batu, tempat bangunan mulai menyebar ke dataran rendah. Perluasan ini mungkin berasal dari paduan semangat: keinginan membuat tempat keagamaan lebih mudah dicapai masyarakat umum dan pengakuan untuk "elit" yang berkuasa bahwa hubungan dengan kekuasaan dewa secara nyata menambah kekuasaan duniawi mereka. Beberapa prinsip dasar yang melatarbelakangi bentuk candi Indonesia adalah kepercayaan pribumi pada kekuatan yang ada dalam nenek moyang dan gunung. Meski agama dan arsitektur India memainkan peran tambahan dalam menghias dan bentuk baru dalam mengungkapkan konsep yang ada sebelumnya, teori India tentang setangkup 
sebagai unsur dasar tata semesta secara nyata menambah konsep prasejarah Indonesia. Seni "klasik" menekankan setangkup dan penempatan unsur-unsur secara tepat, masing-masing dengan tempat yang telah seluruhnya ditentukan dalam susunan (Arismunandar, 2002:52).

Kompleks Candi Kedaton terletak sekitar 900 meter sebelah tenggara Candi Kotomahligai, sekitar 1.580 meter disebelah barat Candi Gedong II, dan 60 meter di Selatan sungai Jambi. Disebelah utara candi pada jarak 70 meter mengalir parit buluh yang juga berhubungan dengan sungai Jambi. Lingkungan situs Candi Kedaton ini masih sebagian besar berupa hutan dan pohon-pohon yang menjulang tinggi akan tetapi sebagian lagi sudah di manfaatkan warga sebagi membuka bercocok tanam.

Di tepian Sungai. Sungai Jambi yang merupakan pecahan dari Sungai Amburan Jalo berada 60 meter di Selatan, sedangkan 70 meter sebelah Utara candi mengalir Parit Buluh yang juga berhubungan dengan Sungai Jambi.

Sungai-sungai kecil dan parit-parit yang beberapa diantaranya menunjukan tanda-tanda sengaja di buat tersebut seolah-olah memisahkan kelompok percandian disini tiga kelompok. Kelompok pertama telatak disebelah timurterdiri dari candi Aston, Candi Kembarbatu, Candi Tinggi, dan Candi Gempung yang dipisahkan oleh sungai Melayu di sebelah barat dan utara, serta sungai Buluran di sebelah Selatan. Kelompok ke dua terdiri dari Candi Gedong I, Candi Gedong II, dan Candi Kedaton yang terletak di tengah, yang seolah-olah dipisahkan oleh sungai Melayu di sebelah timur dan sungai Terusan di sebelah barat. Kelompok ketiga adalah Candi Kotomahligai yang terletak menyendiri di ujung barat laut dengan batas sungai Berembang di sebelah barat (Mundardjito, 2009:37).

Candi Kedaton memiliki luas 45.000 meter persegi, atau sekitar 4,6 hektar,dengan pagar keliling yang membatasinya berukuran $215 \times 250$ meter. Pada halaman pertama di sisi kiri dari arah pintu masuk terdapat kolam. Dihalaman candi kedaton ini terdapat tembok-tembok penyekat yang membagi halaman paling sedikit menjadi 9 halaman. Sistem pembagiaannya terdapat di Candi Gempung, Candi Induk dan Candi Perwara berada di halaman terbesar yaitu halaman VI. Selain Candi Induk dan Perwara, pada kompleks percandian Kedaton ini di duga masih terdapat Sembilan bangunan kuno lagi yang belum ditampakan. Salah satu yang belum ditampakkan diantaranya berada di halaman I yang di perkirakan sebagai gapura, sehingga timbul asumsi bahwa orientasi kompleks Candi Kedaton sebenarnya menghadap ke Utara (Purwanti, 2013:18-19).

Keberadaan Candi Kedaton diketahui pertama kali pada tahun 1976 setelah diadakan kegiatan survei kepurbakalaan dilingkungan Muara Jambi oleh Direktorat Perlindungan Pembinaan Sejarah dan Purbakala. Kegiatan ini berhasil melakukan penggambaran dan pengukuran sementara luas lahan yang terluas dibandingkan percandiaan lainnya, yaitu $55.850 \mathrm{~m}^{2}$ dan bangunan induknya berukuran $28,13 \mathrm{~m} \mathrm{x}$ $25,5 \mathrm{~m}$. keistimewaan lainnya adalah bangunan Induk diisi dengan kerikil-kerikil berwarna putih yang diambil dari Sungai Batanghari bagian hulu (Purwanti, 2012:9).

Kompleks percandian Muara jambi tepatnya candi kedaton memiliki bagian dalam struktur bangunan Bata yang menggunakan batu kerakal sebagai bahan isian. Batu kerakal ini diisikan kedalam kamar-kamar berbentuk persegi yang disisipkan khusus untuknya. Ukuran ruang terbesar adalah 16,25 x 16,25 x 7,20 meter. Jenis-jenis batuannya diantaranya basalt, kuarsa susu, andesit, obsidian, granit, kalsedon, dan konglomerat. Mengingat jenis batuan ini tidak pernah ditemukan di Muara Jambi, diperkirakan berasal dari daerah aliran sungai di Hulu Batanghari sekitar pegunungan Duabelas atau pegunungan 
Tigapuluh sekitar 118 kilometer lurus arah tenggara Muara Jambi. Sebagian batu isisan bangunan induk telah dikeluarkan pada tahun 1978 untuk menghindari pecahnya struktur dinding bata akibat beban yang berlebihan. Pada halaman candi terdapat tembok-tembok penyekat yang membagi halaman paling sedikit menjadi 9 ruang. Sistem pembagiannya mirip dengan Candi Gempung. Bangunan induk dan perwara berada di halaman besar berukuran $92 \times 123$ meter.

Bangunan induk dan perwara Candi Kedaton ini berbeda dengan bangunanbangunan candi yang berada di daerah jawa. bangunan induk dan perwara tidak memiliki garis lurus dengan pintu gerbang utama Candi, ini diakibatkan karena adanya tahapan dalam proses membangun atau pembangunan pada lokasi candi Kedaton.

\section{Nilai Budaya Pintu Gerbang Candi Kedaton}

Nilai dapat diartikan sebagai tolak ukur dari pola pemikiran dan tindakan yang dilandasi oleh perubahan manusia dalam menentukan tujuan hidup. Nilai sangat berkaitan dengan suatu pilihan yang akan menjadi keputusan manusia untuk memutuskan hal-hal yang di anggap baik atau buruk dalam kehidupan. Begitu juga dengan nilai budaya yang merupakan suatu konsep terdiri dari kebudayaan sehingga membentuk suatu konsep yang bernilai dan dianggap penting oleh suatu masyarakat.

Pada bangunan Candi Kedaton Muara Jambi kita dapat mengetahui benar atau tidaknya terdapat pengaruh kebudayaan dari Melayu, Sriwijaya, dan Mataram Kuno, hal ini dapat di lihat dari sudut bangunan dan pintu gerbang yang menghadap langsung ke arah gunung dan aliran sungai untuk mempermudah melakukan aktifitas (Catatan Observasi Langsung 17-18 Maret 2017).

Dalam kebudayaan yang terdapat di Candi Kedaton Muara Jambi, memiliki Kontak antara kebudayaan Indonesia dengan kebudayaan Hindu-Buddha yang berasal dari India telah menghasilkan kekayaan seni Indonesia yang beraneka ragam. Pengaruh itu berlangsung cukup lama yaitu dari abad pertama sampai abad ke-15. Pengaruh kebudayaan tersebut sangat terasa di daerah Jawa, Bali, Kalimantan dan Sumatera. Di daerahdaerah tersebut tersebar peninggalanpeninggalan sejarah dari masa pengaruh Hindu-Buddha yang berupa candi-candi sebagai bangunan keagamaan (Darini, 2016:56).

Pada Situs Candi Kedaton Muara Jambi memiliki pintu gerbang utama yang menghadap ke Utara. Pintu gerbang candi kedaton ini memiliki perbedaan yang mencolok dibandingkan dengan 9 pintu gerbang lainnya yang terdapat pada Candi Kedaton dan candi-candi lainnya di wilayah komplek percandian Muara jambi. Karna dapat di lihat dari reruntuhan bangunan Candi Kedaton yang merupakan pusat dari peninggalan keagamaan hindu-budha dari kerajaan Melayu, Sriwijaya, dan Mataram kuno yang terbesar di bagian wilayah Situs Muara Jambi.

Kebudayaan Hindu Buddha di Indonesia telah berkembang sejak abad ke 5-16 Masehi, yaitu sejak dikenalkannya tulisan dari India pada abad ke $5 \mathrm{M}$ sampai runtuhnya kerajaan Majapahit di Jawa Timur. Bukti dikenalkannya tulisan ditemukan di Kutai, Kalimantan Timur berupa tulisan yang diterakan pada batu berbentuk tugu yang dikenal dengan prasasti Yupa. Peninggalan-peninggalan dari patung-patung Budhis atau Shivait juga ditemukan di Sulawesi Selatan, Sumatera Selatan, Pulau Bangka, Jember dan Jawa Barat. Bangunan Candi yang berasal dari abad ke-5 Masehi juga ditemukan kotakapur, pulau Bangka. Keberadaan bangunan candi di Kotakapur dan temuan arca wisnu menempatkannya sebagai bukti tertua adanya pengaruh India di pulau Sumatera. Bahkan sejak abad ke-7-14 M, sumatera termasyur dengan kerajaan 
Sriwijaya yang pernah beribukota di Palembang dan Jambi (Rangkuti, 2016:117118).

\section{Fungsi Pintu Gerbang Candi Kedaton}

Pintu gerbang berfungsi sebagai penghubung antara bangunan dengan jalan. Pintu ini digunakan untuk jalan keluar masuk kendaraan dan manusia. Pintu gerbang adalah bagian dari macam-macam pintu menurut fungsinya. Fungsi utama dari sebuah pintu gerbang adalah media keluar masuk kendaraan atau manusia, yang berada pada posisi terdepan sebuah rumah tinggal dan langsung menghubungkan antar ruang luar rumah tinggal (jalan raya) dengan halaman depan.

Bangunan pintu gerbang adalah bangunan yang berfungsi sebagai pintu masuk ke kota, atau bangunan suci, atau pemisah antara bagian yang dianggap sakral dengan bagian yang dianggap profan.Dalam analisis morfologi, secara umum pintu gerbang dapat berbentuk pintu gerbang tanpa atap (candi bentar/gapura siblak) dan pintu gerbang beratap (Paduraksa/kori agung). Satuan pengamatan dalam analisis bentuk pada pintu gerbang mencakup bentuk, ukuran, arah hadap, bagian-bagiannya yang dapat dirinci dari bagian kaki, tubuh dan atap yang merupakan komponen utama pada gapura, sedangkan yang merupakan komponen pelengkapnya berupa tangga, pipa tangga, menara sudut dan kemuncak. Dalam analisis teknologi meliputi bahan dan teknik konstruksi. Bahan-bahan yang digunakan berupa batu bata, dalam pendirian gapura dikenal beberapa teknik, yaitu teknik pasak, teknik pasak puritan, teknik sambung langsung, teknik sambungan dengan pasak dan teknik rubbing (gosok). Sama seperti teknik hias pada ragam hias arsitektural bangunan suci, teknik hias (Idris, dkk, 2015:7).

Dalam pintu gerbang utama candi Kedaton ini memiliki tingkatan, ukiran dan bentuk yang berbeda dibandingkan dengan pintu-pintu yang terdapat pada bagianbagian pintu lainnya, ini dikarnakan pintu gerbang utama adalah pintu gerbang yang di yakini bahwa hanya orang-orang bangsawanlah yang mempunyai tingkatan derajat tertinggi yang mampu melewati pintu utama.

Dalam alam pikiran masyarakat tradisional yang religious (religious man), manusia selalu membagi wilayahnya menurut keaktifannya. Keaktifan mana yang di sebut sebagai (sacred), dan mana yang dianggap sebagai (profane). Seperti disebutkan di atas bahwa di dalam ruang yang, segalanya teratur, baik tingkah laku penghuninya amupun struktur bangunannya. Sedangkan di ruang yang profane semuanya serba kacau (chaos) karena tidak atau belum disucikan.

Untuk memudahkan penataan ruang 'sakral', maka ruang arus dibatasi. Dalam wujud fisik, batas tersebut berupa pagar/tembok keliling. Jadi pagar/tembok keliling dalam tata ruang keratin misalnya, tidak hanya berfungsi sebagai elemen untuk tujuan pertahanan/keamanan semata, tetapi juga merupakan batas dari ruang terhadap ruang yang ada di luarnya. Sedangkan gerbang (pintu masuk) merupakan ambang peralihan dari daerah ke daerah. Di dalam ruang yang dibatasi oleh tembok keliling dibuat pengaturan ruang atau masa bangunan berdasarkan kalsifikasi yang diatur dalam kosmografi (Handinoto, 2015:12-13).

\section{Ragam Hias Pintu Gerbang Candi Kedaton}

Ornament merupakan seni hias. Sebagai produk seni, ornament merupakan ekspresi keindahan yang diaplikasikan dalam objek buatan manusia. Selain itu, ornament juga merupakan produk kebudayaan yang digunakan oleh pendukung kebudayaan tersebut dalam kehidupan bersama. Ada banyak istilah yang berkaitan dengan ornament istilah- 
istilah diantaranya seni dekoratif (decorative art), atau seni hias, seni (art of ornament, ornamental art), ornament dan ragam hias (Guntur, 2004:1).

Dalam pada ragam hias arsitektural gapura menggunakan teknik yang sama dengan teknik pendirian gapura, sedangkan teknik hias pada ragam hias dekoratifnya menggunakan teknik pahat. Masyarakat Bugis mengenal ragam hias yang berasal dari benda-benda flora dan fauna meskipun dalam bentuk yang sederhana, selain untuk keindahan, ada beberapa ragam hias yang membentuk makna dalam kehidupan suatu kebudayaan. Salah satunya ialah bunga parangreng (bunga melati), tumbuhan menjalar yang tidak putus-putusnya, sehingga diumpamakan rezeki yang terus menerus tanpa putus (Idris, dkk, 2015:7).

Pintu gerbang yang terdapat di kompleks percandian Muara Jambi khususnya Candi Kedaton ini memilik ragam hias dan relif tersendiri yang berupa seni ukir teratai di sudut pintu gerbang utama luar. Relief merupakan suatu bentuk dari hiasan yang terdapat dalam karya arsitektur berupa bangunan candi, pertirtaan, gua-gua, punden berundak, pintu gerbang dan lainlainnya. Dalam pengertian yang lebih luas relif merupakan bagian dari karya arsitektur, selain memiliki nilai estiteka juga memiliki nilai simbolis religious dan dapat menentukan identitas keagamaan suatu karya arsitektur. Pada umumnya relif dipahatkan pada bidang datar baik dibagian kaki, badan maupun atap bangunan, dan pada bagian-bagian bangunan yang berperan sebagai bentuk keharmonisan bangunan candi (Idris, dkk, 2015:19)

Selain terdapat seni ukir yang berbentuk bunga teratai,di sisi luar pintu gerbang juga terdapat satu mekara di bagian sebelah kiri, sedangkan di sebelah kanan tidak ditemukan adanya mekara. Makara yang terdapat di sebelah kiri memiliki tinggi $48 \mathrm{Cm}$. makara bagian luar ini memiliki tiga simbol yaitu simbol utama bagian kepala berbentuk gajah, badan ular, buntut ikan dan dibawah badan terdapat hewan domba. Sehingga menambah keanggunan bentuk dari ciri pintu gerbang candi kedaton.

Makara adalah sebuah atau semacam hiasan pada kepala tangga dari sebuah bangunan candi. Biasanya makara itu berlanjut atau bersambung dengan kala, yang semacam hiasan di atas setiap pintu atau relung candi. Tangga sebuah candi biasanya di hiasi oleh dua buah Makara, yaitu dikiri dan di kanan tangga stuttherheim berpendapat bahwa motif makara itu berasal dari gambar buaya yang mukanya telah disamarkan sedemikian rupa dengan berbagai motif hiasan lainnya seperti, daundaunan, sulur-suluran, dan sebagainya. N.J. Krom berpendirian lain lagi dengan menyatakan bahwa motiv dasar sebuah makara berasal dari gambar berkepala gajah berbadan ikan.

Dalam daerah propinsi Jambi baru terdapat dua buah Makara candi yang terbuat dari batu alam. Pertama di Solok Sipin, Kotamadya Jambi. Ditemukan pada masa penjajahan Belanda dan kini tersimpan di Museum Pusat Jakarta. Makara yang kedua terdapat di daerah Muara Jambi, hasil penggalian di samping Candi Gempung. Dalam pengamatan sepintas lalu, motif hiasan pada kedua makara itu hampir bersamaan. Dr. Soekmono menyebutkan Makara dari SolokSipin itu sebagian besar makara yang terbesar di Indonesia yang mempunyai angka tahun yang sesuai dengan tahun 1964 Masehi (Nazir, 1981:32-33).

\section{Makna Simbolik (Pembatas) Pintu Gerbang Candi Kedaton}

Menurut (Barger, 2010:27), Simbol adalah jenis tanda di mana hubungan antara penanda dan petanda seakan-akan bersifat arbitrer. Suatu simbol merupakan sesuatu yang memiliki signifikasi dan resonansi kebudayaan. Simbol tersebut memiliki kemampuan untuk mempengaruhi dan memiliki makna mendalam. Sebagaimana 
telah ditunjukan, para penganut Saussure memandang symbol secara konvensional. Kita mempelajari simbol dan mengasosiasikannya dengan semua jenis kejadian, pengalaman dan sebagainya yang sebagian besar memiliki pengaruh emosional bagi kita dan orang lain. Simbol keagamaan selalu berada pada puncak gunung dari pristiwa sejarah, legendalegenda dan sebagainya dan memiliki kekuatan untuk mengarahkan pikiran dari sebagian besar seluruh materi. Karena itu, symbol membantu kita untuk tanggap terhadap sesuatu. Simbol-simbol membantu kita mempertajam tingkah laku dan prestasi kebudayaan dan mempertimbangkan simbol seakan-akan memiliki motivasi bahwa kita seharusnya tidak menekankan sifat ilmiahnya. Pemahaman kita tentang symbol (dan jenis-jenis tanda lainnya) sering tergantung pada apa yang kita terapkan pada simbol-simbol yang akan menjadi budaya kita (Barger, 2010:28-29).

Dari hasil penelitian dan pengamatan serta penjelasan di atas bahwa simbol merupakan hal yang terdapat di suatu bangunan atau benda untuk menandakan bangunan tersebut memiliki arti dan makna tersendiri. Begitu juga yang terdapat pada makna atau simbol pintu gerbang utama candi kedaton memiliki unsur religi atau keagamaan hinddu-buddha. Dalam pemberian simbol di candi Hindu-Budha tidak semata-mata hanya memiliki makna semantis saja, melainkan juga sebagai suatu bentuk doa dalam wujud sebuah simbol-simbol yang di beri nama tertentu. Bangunan candi yang juga di anggap sebagai suatu tempat peribadatan, sudah sewajarnya apabila semua unsur yang ada didalamya merupakan perwujudan doa untuk Sang Dewa. Seperti yang kita ketahui bahwa masyarakat zaman dahulu memiliki hubungan erat dengan kemurnian alam. Hal tersebut terbukti bahwa dalam setiap fitur yang ada dalam candi selalu dikaitkan dengan keadaan alam sekitar. Simbol yang terdapat pada pintu gerbang ini dapat di lihat dari makara yang memiliki lambang hewan ikan, gajah, dan ular. berunsur keagamaan hinddu- buddha.

Makna dari simbol yang terdapat di nekara, yaitu:

a) Gajah

Gajah merupakan salah satu hewan yang kerap dikaitkan dengan keberadaan nekara sebagai salah satu produk dari budaya Dong Son.bahkan pemahatan sosok gajah yang berbahan batu juga ditemukan di Sumatra Selatan diantaranya di situs gunung Megang, disitus pulau panggung, Lahat. Gajah di situs dimaksud dipahatkan dalam posisi sebagai hewan tunggangan seseorang. Di dalam pahatan tersebut diantaranya juga digambarkan lelaki memakai gelang tangan dan kak, pedang, dan nekara. Hal tersebut menggambarkan bahwa gajah merupakan hewan yang memiliki nilai tinggi, sehingga sangat umum digunakan pada produk-produk budaya masa itu (Restiadi, 2012:159).

b) Ikan Ikan salah satu hewan yang dikaitkan dengan dunia bawah bagi masyarakat batak, sehingga hewan ini memiliki status sosial yang rendah. dalam struktur hewan yang terkait dengan religi. Hewan ini (ikan) selain sebagai persembahan dalam ritual juga dijadikan buah tangan kerabat yang sosialnya lebih tinggi (tulang/hula) jika hendak mengunjungi kerabat dalam status sosial yang lebih rendah (Boru/bere) sehingga ikan juga merupakan symbol penghormatan dan sekaligus menunjukan status bahwa si pembawa buah tangan itu memiliki status sosial yang lebih tinggi (Restiadi, 2012:170).

c) Ular

Ular merupakan salah satu jenis hewan melata lainnya, yang juga kerap dipahatkan pada bangunan 
megalitik, seperti yang terdapat di pasemah (Sukendar, 1984:14). Ular merupakan hewan yang ditakuti oleh masyarakat karna bias/racunnya yang mematikan. Pahatan ular lainnya ditemukanpada situs batu gajah di Simalungun, yang dikaitkan dengan konsep dunia bawah yang mengacu kepada tanah. Seperti diketahui masyarakat pada masa megalitik memiliki dengan konsep ibu pertiwi yaitu yang disimbolkan sebagai penguasa tanah, sehingga keberadaan ular tersebut di indikasikan berkaitan dengan kesuburan.

Ular atau hewan dengan bentuk yang lebih menyeramkan juga digambarkan pada masyarakat tradisonal seperti masyarakat Hinddu dan juga masyarakat tradisi megalitik. Ular yang besar yang kerap di sebut naga tersebut direprentasikan sebagai hewan penguasa air/ hutan/ lautan/ danau/ sungai. Oleh karna itu, hewan ini kerap dikaitkan dengan masyarakat yang banyak aktivitasnya pada areal yang mengandung air., bermata pencarian sebagai nelayan atau memiliki latar belakang kehidupan bersinggungan langsung dengan air (Restiadi, 2012:161).

Makna simbol makara yang terdapat pada pintu gerbang Candi Kedaton ini merupakan tinggalan budaya situs dari Solok Sipin. Pada pintu gerbang Candi Kedaton sebenarnya terdapat empat buah makara. Masing-masing berukuran tinggi 1,10 meter, 1,21 meter, 1,40 meter, dan 1,41 meter, pada setiap sisi makara terdapat hiasan raksasa yang seolah-olah. Setiap raksasa membawa tali dan sebuah tongkat besar yang di bagi ujungnya yang terdapat kuntum bunga.

Salah satu dari empat buah makara yang ditemukan dari Solok Sipin mempunyai pertanggalan 986 Saka atau 1064 Masehi dan tulisan yang berbunyi mpu Dharmmawira. Prasasti angka tahun ini ditemukan pada tahun 1902 dan pertama kali dibaca dan di terbitkan oleh Brandes (1902:34-36). Hiasannya berupa dua raksasa yang masing-masing memegang lingkaran tali di hadapan bahu kanannya, dan satu raksasa lagi membiarkan memakai tali cawat, subang, telinga, gelang tangan, dan gelang kaki. Hiasannya yang dipahatkan pada makara yang menunjukan suatu gaya seni yang tinggi yang dapat di sejajarkan dengan gaya seni yang terbaik di Jawa yang berkembang pada abad ke- 8 Masehi (Sulaiman, 1976:3). Dilihat ukuran makara yang cukup besar, menunjukan berasal dari sebuah bangunan yang besar (Utomo, 2011:61-62).

Para ahli memperkirakan bahwa Situs Muara Jambi pada masanya (antara abad ke-12-13) merupakan pusat aktivitas agama Mahayana yang cukup ramai. Sisa-sisa bangunan yang merupakan bekas wihara atau dharmmasala mengindikasikan banyaknya kaum agamawan yang melakukan ritual peribadatan di pusat keagamaan tersebut (Darini, 2016:46).

Aliran agama Buddha Hinayana merupakan aliran agama yang pada awalnya berkembang pesat di Sriwijaya (Sumatera). Hal ini ditentukan dari sumbersumber Cina. Para pendeta Cina yang datang ke Sumatera dan Jawa justru mempelajari kitab-kitab agama Buddha Hinayana. Namun demikian dalam perkembangannya aliran Hinayana ini justru terdesak oleh perkembangan ajaran Buddha Mahayana, baik di Jawa, maupun Sumatera. Perkembangan aliran Buddha Mahayana di Sumatera dikuatkan dengan peninggalanpeninggalan material berupa monumen, arca, relief maupun prasasti. Kemungkinan besar aliran Mahayana yang meluas karena adanya dukungan dari dinasti raja-raja yang kuat, yaitu Dinasti Syailendra. Di wilayah Jambi banyak ditemukan benda-benda kepurbakalaan dari bata. Oleh masyarakat setempat situs tersebut dinamakan Candi 
Astanao, Candi Tinggi, Candi Gumpung, Candi Kembar Batu, Candi Kedaton, Candi Gedong dan lain-lain (Darini, 2016:45-46).

Candi dalam kosmologi HindduBuddha merupakan simbol atau replika dari gunung Meru. Ekspresi gunung yang menjulang tinggi dimaknai sebagai penghubung bumi dan langit. Gambaran lingkungan kosmos ditandai dari desain halaman di tata bertingkat-

tingkat dan memusat dengan halaman pusat di

tempat tertinggi, candi sebagai lambing gun ung Meru terletak di tengah sebagai pusat dunia. Dengan pengertian itulah, masyarakat pada waktu itu membang un candi berharap dapat hidup sedekat mungkin dengan pusat dan dapat berkomunikasi dengan dunia transcendental.

\section{SIMPULAN}

Pintu gerbang candi Kedaton adalah salah satu nilai budaya yang tertinggi pada masa persebaran agama Buddha yang berasal dari abad ke 9-12 Masehi. Kebudayaan yang terkandung dalam pintu gerbang candi kedaton merupakan seni kebudayaan bermutu tinggi dari peninggalan kerajaan Mataram Kuno, Sriwijaya, dan Malayu. Menurut observasi penulis menemukan fakta bahwa kebudayaan yang terdapat di pintu gerbang candi kedaton lebih tinggi peradabannya dari pada candicandi yang berada disekitar situs perkomplekan Muara Jambi ini dibuktikan dari luas dan bentuk bangunan pintu gerbang yang memiliki symbol makara, tulisan kuno pada sudut pintu gerbang, serta ragam hias teratai di sudut pintu gerbang kiri kanan yang melambangkan kejayaan pada masa peninggalan agama Buddha, dan peninggalan pada masa kerajaan ini berupa bangunan candi yang terbuat dari bangunan-bangunan bata mengelompok di suatu tempat yang dikelilingi tembok pagar keliling di kawasan candi Kedaton situs
Muara Jambi, kecamatan Marosebo, kabupaten Muara Jambi, provinsi Jambi.

\section{DAFTAR PUSTAKA.}

Barger, Arthur Asa. 2010. Pengantar Semiotika. Yogyakarta: Tiara Wacana.

Darini, Ririn. 2016. Sejarah Kebudayaan Indonesia Hindu-Budha. Yogyakarta: Ombak.

Guntur. 2004. Ornamen Sebuah Pengantar. Surakarta: STSSI PRESS.

Handinoto. 2015. Perkembangan Kota di Jawa. Yogyakarta: Ombak.

Arismunandar, Agoes, dkk. 2002. Arsitektur. Jakarta: PT. Widyadara.

Idris, Muhamad, dkk. 2015. Modul Praktek Mata Kuliah Sejarah Indonesia 1. Palembang: Universitas PGRI Palembang.

Ismail, Arlan. 2003. Periodisasi Sejarah Sriwijaya. Palembang: Unanti Press.

Mundardjito. 2009. Muara Jambi Dulu, Sekarang, dan Esok. Palembang: Balai Arkeologi.

Nazir. 1980. Arkeologi Klasik Daerah Jambi. Jambi: Museum Negeri Provinsi Jambi.

Purwanti, Retno. 2013. Fungsi Halaman Kompleks Candi Kedaton Muara Jambi Kabupaten Muara Jambi Provinsi Jambi. Palembang: Jurnal Siddhayantara. Vol. 18, No.1:18-26.

Rangkuti, Nurhadi. 2016. Kerincimu Kerinciku Dartaran Tinggi dalam Perspktif Arkeologi. Yogyakarta: Ombak.

Restiyadi, Andri. 2012. Fauna Dalam Arkeologi. Medan: Balai Arkologi.

Riandini, Nursanti. 2009. Zamrud Khatulistiwa Indonesia. Jakarta: Bee Media Indonesia.

Utomo, Bambang Budi. 2011. Kebudayaan Zaman Klasik Indonesia di Batang Hari. Jambi: Dinas Kebudayaan dan Pariwisata. 
Usman, Husnaini, Purnomo Setiady Akbar. 2014. Metodelogi Penelitian Sosial. Jakarta: Bumi Aksara. 